\title{
Induction of HaCaT Cell Apoptosis by Sodium Nitroprusside
}

\author{
Yuri Park ${ }^{1}$, Cheol Moon ${ }^{2}$, Sa-Hyun Kim² ${ }^{2}$ and Pyeongjae Lee ${ }^{1}$ \\ ${ }^{1}$ Department of Natural Medicine Resources, Semyung University, Jecheon 27136, Korea \\ ${ }^{2}$ Department of Clinical Laboratory Science, Semyung University, Jecheon 27136, Korea
}

\section{Sodium Nitroprusside로 유발한 HaCaT Cell의 Apoptosis}

\author{
박유리 ${ }^{1},{\text { 문 } \text { 철 }^{2}, \text { 김사현 }}^{2}$, 이평재 ${ }^{1}$ \\ 세명대학교 ${ }^{1}$ 자연약재과학과, ${ }^{2}$ 임상병리학과
}

\begin{abstract}
Nitric Oxide (NO) has been known to play important physiological and pathological roles. In this study, Sodium nitroprusside (SNP), NO donor, induced the apoptosis of HaCaT cell, human spontaneous immortal keratinocyte, which was investigated through DAPI staining and cleavage of PARP and caspase -3 protein. However, the expression level of Bip and CHOP, involved in ER stress, was not significantly changed as compared to the control cell group. Recent studies have showed that SIRT1, NAD ${ }^{+}$-dependent deacetylase, is the key protein that controls cell survival and death. SNP treatment suppressed the SIRT1 gene expression, which indicated that apoptosis induced by SNP could be implicated in SIRT1 down-regulation.
\end{abstract}

Keywords: Apoptosis, Nitric Oxide, HaCaT, SIRT1

This is an Open Access article distributed under the terms of the Creative Commons Attribution Non-Commercial License (http://creativecommons.org/licenses/by-nc/4.0) which permits unrestricted non-commercial use, distribution, and reproduction in any medium, provided the original work is properly cited.

Copyright @ 2015 The Korean Society for Clinical Laboratory Science. All rights reserved.
Corresponding author: Pyeongjae Lee Department of Natural Medicine Resources, Semyung University, Jecheon 27136, Korea Tel: 82-43-649-1411

E-mail: pjlee1@semyung.ac.kr

Received: June 1, 2015 Revised: June 19, 2015 Accepted: June 23, 2015

\section{서 론}

인체 피부는 크게 표피, 진피, 피하조직으로 구성되어 있다. 외부 환경으로부터 신체 내부를 보호하거나 보습, 체온조절 등 중요한 역할을 한다. Keratinocyte는 표피를 구성하는 가장 중요한 세포로 표피세포의 $90 \sim 95 \%$ 를 차지한다. 이러한 keratinocyte는 연속적 으로 자외선뿐만 아니라 화학물질을 포함한 다양한 환경적, 생리적 스트레스에 노출되어 있다.

산화질소(Nitric oxide, $\mathrm{NO}$ )는 임상적으로 중요한 의미가 있는 매개체로서 세포 간 신호 전달기능과 세포독성의 주요한 생리학적 병리학적 기능이 있다. NO가 어떤 기능을 하는가는 nitric oxide synthase (NOS)의 type, target cell type, 농도 등에 의존한다. $\mathrm{NO}$ 가 피부에 미치는 영향과 관련하여 keratinocyte cell migration
촉진(Zhan 등, 2015), wound healing (Spitler 등, 2013), melanocyte에서 melanin 생성 유도(Romero-Graillet 등, 1997), ultra violet B (UVB)에 의한 피부 홍반 유도(Deliconstantinos 등., 1995)가 보고되었다. Bastianetto 등(2010)은 resveratrol이 NO donor인 sodium nitroprusside (SNP)로 유발한 HaCaT cell (human keratinocyte cell type) apoptosis를 저해한다고 보고하 였다. 본 연구에서는 기존 연구에 더하여 $\mathrm{HaCaT}$ 세포에 SNP 처리 했을 때, apoptosis관련 Poly (ADP-riose) polymerase (PARP), caspase-3 단백질의 절단을 확인하였고 endoplasmic reticulum (ER) stress관련 유전자 발현에 변화는 없으나 $\operatorname{sirt} 1\left(\mathrm{NAD}^{+}\right.$의존 deacetylase) 유전자 발현은 억제됨을 확인하였다. 


\section{재료 및 방법}

\section{1. 시약}

본 실험에서 사용한 sodium nitroprusside dehydrate (SNP), 3-(4,5-dimthylthiazol-2-yl-2,5-diphenyl-tetrazolium bromide (MTT), 4',6-diamidino-2-phenylindole (DAPI)는 Sigma 제품을 사용하였다. Dulbecco's modified Eagle Medium (DMEM)은 Lonza에서 Fetal bovine serum (FBS), Penicillin/Streptomycin은 Gibco에서 구입하였다.

\section{Cell culture}

본 실험에 사용된 $\mathrm{HaCaT}$ 은 세명대학교 임상시험센터에서 분양 받아 사용하였다. 세포는 10\% (v/v) FBS와 1\% (v/v) Penicillin/Streptomycin가 함유된 DMEM 배지에 $37^{\circ} \mathrm{C}, 5 \% \mathrm{CO}_{2}$ 의 배양기에 서 배양하였다. $\mathrm{HaCaT}$ 은 일주일에 3 4회 1:3 비율로 계대배양 하였다.

\section{MTT assay}

세포 생존율은 MTT 방법으로 측정하였다. MTT 방법은 세포의 살아있는 정도를 간접적으로 측정하는 방법으로 미토콘드리아의 탈수소효소가 노란색의 수용성 기질인 tetrazolium을 청자색을 띠 는 비수용성의 formazan으로 환원시키는 능력을 이용하는 검사법 이다. 세포는 $2.0 \times 10^{4}$ cells/well의 농도로 96 well plate에 분주 하여 24시간 배양 후 시료를 처리하여 24시간 후에 세포 생존율을 측정하였다. MTT용액 $(5 \mathrm{mg} / \mathrm{ml}) 20 \mu$ 를 각 well에 가하고 2시간 동안 반응시킨 후 상등액을 제거하고 $100 \mu \mathrm{L}$ 의 $\mathrm{DMSO}$ 를 첨가하여 생성된 formazan결정을 용해시켜 $570 \mathrm{~nm}$ 에서 흡광도를 측정하 였다. 생존율은 대조군에 대한 백분율로 나타내었다.

\section{DAPI staining}

$\mathrm{HaCaT}$ 세포에 10시간 SNP 처리 후 세포를 모았다. $37 \%$ formaldehyde 용액과 PBS를 1:9의 비율로 섞은 fixing solution 1 $\mathrm{mL}$ 을 세포에 첨가하여 잘 섞은 후 실온에서 10 분 동안 고정하였다. $3000 \mathrm{rpm}$ 으로 2분간 원심 분리 한 후 상층액을 제거하고 Phosphate buffered saline (PBS)로 2번 washing하였다. 세포 pellet을 PBS $1 \mathrm{~mL}$ 로 부유한 후 DAPI $10 \mu \mathrm{L}$ 넣고 빛을 차단하여 실온에서 20분 동안 반응하였다. $3000 \mathrm{rpm}$ 으로 2분간 원심 분리 한 후 PBS $50 \mu \mathrm{L}$ 를 섞어 주었다. $5 \mu \mathrm{L}$ 을 slide glass 위에 떨어 뜨려 coverslip 덮고 현광 현미경으로 핵의 형태를 관찰하였다.

\section{Reverse transcription-polymerase chain reaction (RT-PCR)}

$\mathrm{HaCaT}$ 세포 $\left(40 \times 10^{4}\right.$ cells $\left./ \mathrm{mL}\right)$ 를 $35 \varnothing$ dish에 seeding하고 $24 \mathrm{~h}$ 뒤시료를 처리하였다. 일정시간 뒤에 Easy-BLUETM를 이용 하여 total RNA를 분리한 다음 정량하였다. Total RNA $2 \mu \mathrm{g}$ 에 oligo-d(T) primer $(0.2 \mathrm{mM}) 1 \mu \mathrm{L}$ 를 혼합하여 $75^{\circ} \mathrm{C}$ 에서 10 분간 반응 시켰다. RNase inhibitor (10 U/ $\mu \mathrm{L}) 1 \mu \mathrm{L}$ 와 5X RT buffer 4 $\mu \mathrm{L}$, dNTP (10 mM) $2 \mu \mathrm{L}$, DTT (0.1 M) $2 \mu \mathrm{L}$, AMV RT enzyme $(10 \mathrm{U} / \mu \mathrm{L}) 0.5 \mu \mathrm{L}$ 를 첨가 한 후 diethyl pyrocarbonate (DEPC)로 처리된 증류수를 이용하여 전체 양을 $19 \mu \mathrm{L}$ 로 보정하였다. $42^{\circ} \mathrm{C}$ $60 \mathrm{~min}$, 그리고 $70^{\circ} \mathrm{C}$ 에서 $5 \mathrm{~min}$ 반응하여 $\mathrm{CDNA}$ 를 합성한 후 희석 하였다. $\mathrm{CDNA}$ 와 각 유전자 primers를 이용하여 RT-PCR반응을 수행하였다. 반응 조건은 Template $2 \mu \mathrm{L}$ 와 primers (10 pmol, Table 1) $1 \mu \mathrm{L}, \mathrm{PCR}$ pre-Mix $15 \mu \mathrm{L}, \mathrm{DEPC}-w a t e r ~ 11 \mu \mathrm{L}$ 첨가하여 전체 양을 $30 \mu \mathrm{L}$ 로 하여 $\mathrm{PCR}$ 반응을 수행하였다. $\mathrm{PCR}$ 반응으로부 터 획득한 증폭산물을 $1.5 \%$ agarose gel을 이용하여 전기영동하였다.

\section{Western blotting}

$\mathrm{HaCaT}$ 세포 $\left(60 \times 10^{4}\right.$ cells $\left./ \mathrm{mL}\right)$ 를 $35 \varnothing$ dish에 seeding하고 $24 \mathrm{~h}$ 뒤 SNP를 처리하였다. 세포를 proteinase inhibitor (PMSF, $100 \mu \mathrm{g} / \mathrm{mL}$, Aprotinin $1 \mu \mathrm{g} / \mathrm{mL}$ )가 첨가된 triple detergent lysis buffer (50 mM Tris-Cl pH 8.0, 150 mM NaCl, 0.1\% SDS, 1\% NP40, 0.02\% Sodium azide, 0.5\% Sodium deoxycholate)로 용 해하여 단백질 시료를 얻은 후 BCA protein assay kit 이용하여 정 량 하였다. 단백질을 SDS-PAGE 한 후, Nitrocellulose에 Trans blot turbo blotting 기계를 이용하여 이동시켰다. Membrane을 $5 \%$ skim milk 용액으로 2시간 동안 blocking하였다. 1차 항체 PARP (Cell signaling, 1:5000), Caspase-3 (Cell signaling, $1: 3000$ ), $\beta$-actin (Santa Cruz, 1:3000)를 처리하여 $4^{\circ} \mathrm{C}$ 에서 반응 하였다. TBST로 3회 washing후, 2차 Horse radish peroxidase (HRP) linked anti-rabbit IgG (Santa Cruz) 혹은 HRP linked anti-mouse IgG (Santa Cruz)를 첨가하여 1시간 실온에서 교반 하였다. TBST로 3회 washing한 후, ECL와 반응시킨 다음 이미지

Table 1. Primers

\begin{tabular}{lcc}
\hline Gene & \multicolumn{1}{c}{ Forward $\left(5^{\prime} \rightarrow 3^{\prime}\right)$} & Reverse $\left(5^{\prime} \rightarrow 3^{\prime}\right)$ \\
\hline GAPDH & ATTGTTGCCATCAATGACCC & AGTAGAGGCAGGGATGAGGT \\
Sirt1 & TCAGTGTCATGGTTCCTTGC & AATCTGCTCCTTTGCCACTCT \\
CHOP & ATGAGGACCTGCAAGAGGTCC & TCCTCCTCAGTCAGCCAAGC \\
Bip & CCTGGGTGGCGGACCTTCG & CTGGACGGGCTTCATAGTA \\
\multicolumn{2}{c}{ ATGTG } & GACCGG \\
\hline
\end{tabular}


분석시스템을 이용하여 band를 확인하였다.

\section{Statistical analysis}

실험결과는 mean \pm S.D.로 표현하였다. Student t-test를 통해 $p<0.05$ 이하인 경우를 유의한 것으로 판정하였다.

\section{결 과}

\section{SNP의 농도 및 처리시간에 따른 $\mathrm{HaCaT}$ 의 생존율 및 NO} 생성량의 변화

$\mathrm{SNP}$ 을 농도 별 $(0.1,0.5,1,2,3 \mathrm{mM})$ 처리하고 24시간 후, 실행 한 MTT assay 결과 $1 \mathrm{mM}$ 에서 약 20\% 생존율이 증가 하였고, 2 $\mathrm{mM}$ 에서부터 생존율이 떨어져서 $3 \mathrm{mM}$ 에서는 대조군 대비 약 $50 \%$

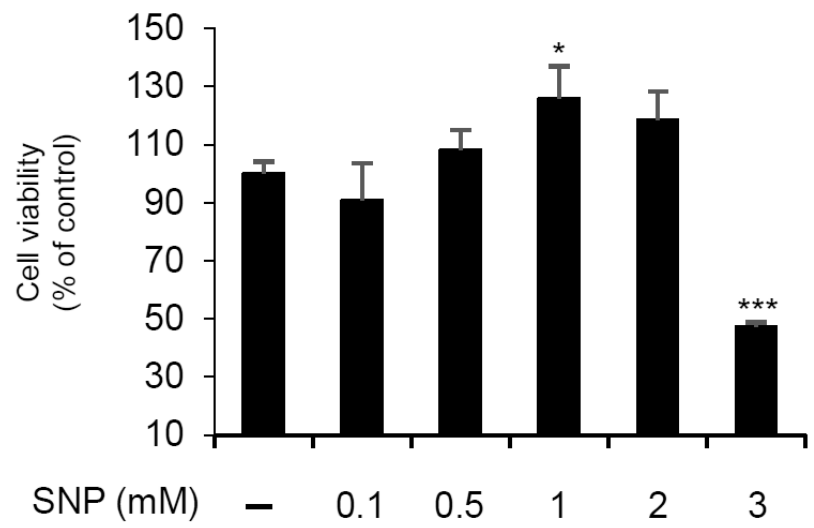

Fig. 1. Effect of SNP on cell viability in HaCaT cells. Cells were exposed to varying doses $(0.1,0.5,1,2,3 \mathrm{mM})$ of SNP. Cell viability was determined 24 hours later using the MTT method. Values present mean \pm S.D. of three separate experiments. ${ }^{*} p<0.05$, ${ }^{\star * \star} p<0.001$.
의 세포독성을 보였다(Fig. 1A).

\section{SNP에 의한 apoptosis}

$\mathrm{SNP}(3 \mathrm{mM})$ 처리 10시간 후 DAPI로 핵을 염색했을 때 대조군에 비하여 염색사의 응축과 단절을 확인할 수 있었다(Fig. 2A). NO에 의한 ER stress증가를 확인하기 위해 SNP (3 mM) 처리 후 Bip과 $C H O P$ 유전자 발현을 시간대별로 RT-PCR로 확인하여 보았다. Bip 와 $C H O P$ 유전자 발현은 대조군과 비교하여 볼 때 큰 변화가 없었다 (Fig. 2B). PARP와 caspase-3의 경우 SNP (3 mM)처리 후 6시간에 서 절단된 PARP와 caspase-3를 확인 할 수 있었다(Fig. 2C, 2D).

\section{SNP에 의한 sirt1의 발현 감소}

$\mathrm{SNP}$ (3 mM) 처리 후 시간대별로 $\operatorname{sirt} 1$ 의 유전자 발현 정도를 RT-PCR로 확인하였다. 2시간에서는 대조군과 비교했을 때 큰 변 화를 보이지 않았으나 4시간과 6시간에서 $\operatorname{sirt1}$ 의 발현량이 줄어든 것을 확인하였다(Fig. 3).

\section{고 찰}

$\mathrm{NO}$ 는 생체 내에서 신호전달자로서 cell type 사이에 정보를 전 달하여 다양한 반응을 일으킨다. NO는 세포를 보호하기도 하고 cell death를 유발하기도 한다. 실제 ultra violet B에 노출한 Keratinocyte에 내재적 NO합성 효소 저해제를 처리했을 때 apoptosis가 증가하는데 이는 NO가 cell toxicity 방어효과가 있 음을 나타낸다(Weller 등, 2003). 이 논문에서 iNOS 과발현을 유도 할 때 UVB에 노출하지 않았음에도 약 $20 \%$ 생존율이 증가함을 보 였다. 본 실험에서도 SNP 처리시 농도 의존적으로 cell death가 나 타나는 것이 아니라 $1 \mathrm{mM}$ 에서 오히려 약 $20 \%$ 세포가 늘어나는 것
A
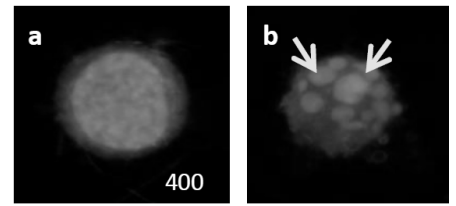

C

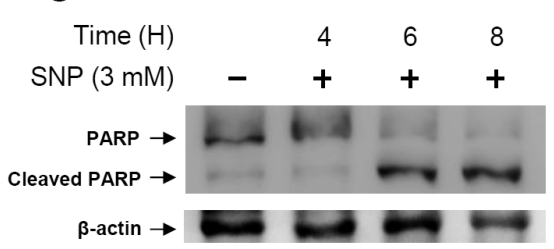

B

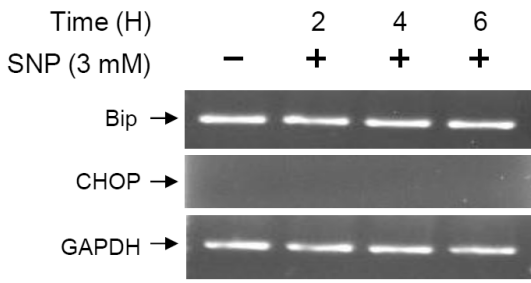

D

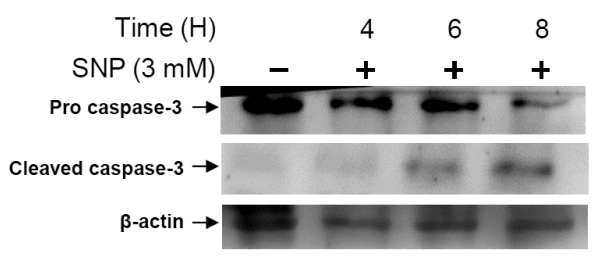

Fig. 2. Induction of Apoptosis by SNP (A) DAPI staining was carried out 10 hours after SNP treated to $\mathrm{HaCaT}$ cells. (a) Control, (b) SNP (3 mM). (B) RT-PCR for Bip and CHOP was performed. (C) and (D). Western blotting for PARP and caspase- 3 was performed. 


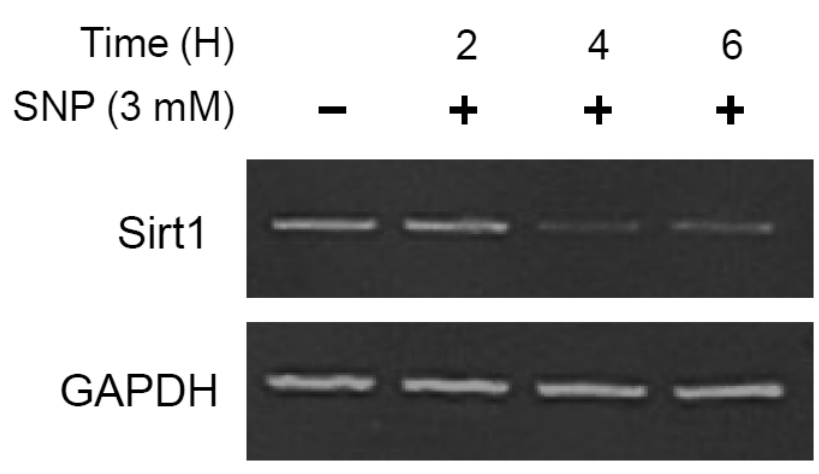

Fig. 3. Suppression of Sirt1 mRNA expression by SNP. RT-PCR for Sirt1 was carried out indicated-time after SNP (3 mM) treated to HaCaT cells.

을 볼 수 있었고 $3 \mathrm{mM}$ 에서 급격히 떨어지는 것을 확인할 수 있었 다. 이는 상대적으로 낮은 농도의 $\mathrm{NO}$ 에서는 세포증식 효과를 보이 며 고농도에서는 cell death를 유발한다고 생각된다. NO는 macrophage (Messmer와 Bruner, 1995), osteoblast (Chen 등, 2002), cardic muscle cell (Chae 등, 2001) 등 다양한 cell type에 서 apoptosis를 일으킨다. NO가 apoptosis를 일으키는 기전은 미 토콘드리아 의존적으로 보고되는데 NO에 의한 DNA 손상은 p53 단백질의 축적을 일으키며 이는 미토콘드리아의 막전위를 파괴하 며 cytochrome c의 세포질 내 배출을 유도한다. 배출된 cytochrome C는 apoptosome을 형성하여 caspase-9를 절단 활성화시키며 다시 활성화된 caspase-9는 caspase-3를 절단 활성화시킨다. caspase-3는 PARP를 절단 DNA 손상 복구 기전을 무력화시킨다. $\mathrm{HaCaT}$ cell은 p53이 mutation 되어 있는 세포로서 NO에 의한 $\mathrm{DNA}$ 손상이 $\mathrm{p} 53$ 의 안정화를 일으킨다 하여도 안정화된 $\mathrm{p} 53$ 이 apoptosis에 대한 기여도가 작을 수 있다. Kawahara 등(2001)은 p53 protein이 정상적이지 않은 microglia 세포에서 NO가 ER stress를 통해 apoptosis를 일으킨다고 보고했고 $\beta$-cell과 chondrocyte에서도 NO에 의한 apoptosis가 ER stress 의존성임이 보고 되었다(Oyadomari 등, 2001, Takada 등, 2013). 따라서 $\mathrm{HaCaT}$ 세포에서도 NO가 ER stress를 통해 apoptosis를 일으킬 가능성이 있다. ER은 비정상적으로 형성된 단백질 구조를 복구시키는 기능 을 갖는다. NO에 단백질 구조의 변성은 ER로 하여금 단백질 구조 복구를 위한 단백질 발현을 유도하며 그 한계를 벗어나게 되면 apoptosis를 유발하는 기전이 활성화 된다. 본 실험에서 human keratinocyte cell type인 HaCaT cell을 대상으로 하여 NO donor 인 SNP을 처리한 후에 apoptosis가 일어남을 확인하였다. SNP에 의한 HaCaT의 apoptosis는 이미 보고된 바 있는데 이 논문에서는 SNP에 의해 caspase의 활성이 증가함을 보이고 있다(Bastianetto 등, 2010). 본 논문에서는 apoptosis에 관련하는 것으로 보이는 caspase-3와 이것의 기질로 $\mathrm{DNA}$ 복구에 관여하는 $\mathrm{PARP}$ 의 절단 을 western blot을 통해 확인하여 $\mathrm{NO}$ 에 의한 $\mathrm{HaCaT}$ 의 apoptosis 는 caspase-3의 활성화를 통한 pathway가 관여함을 보였다. ER stress와 관련하여 단백질 구조 복구 및 apoptosis 연결과 관련되 는 것으로 알려진 $\mathrm{Bip}$ 및 $\mathrm{CHOP}$ 유전자의 발현량을 확인한 결과 대 조군과 별다른 차이를 나타내지 않아 NO에 의한 $\mathrm{HaCaT}$ cell의 apoptosis에 ER stress 영향이 그다지 크지 않은 것으로 생각된다.

Sirt 1은 $\mathrm{NAD}^{+}$-의존 deacetylase로서 전사인자의 acetyl group 을 제거한다. Sirt1의 기질로는 p53 (Luo 등, 2001), NF-kB (Yeung 등, 2004), FoxO (Hughes 등, 2011)등이 있으며 이들 전사인자를 탈아세틸화 시켜 세포 손상 복구와 세포 증식을 촉진시키는 것으로 알려져 있다. 최근 human keratinocyte에 $\mathrm{H}_{2} \mathrm{O}_{2}$ 와 UVB 처리 해 주 면 Sirt1의 발현양이 줄어들며 이것이 apoptosis와 관련 있다는 보 고(CaO 등, 2009)와 Sirt 1의 저해가 apoptosis에 대한 민감성을 증가시킨다는 보고(Herbert 등, 2014)는 kerationcyte의 apoptosis 에 Sirt1이 상당히 관계있음을 보여준다. 본 실험에서 cell death를 유발하는 SNP 농도에서 HaCaT cell에서 Sirt1 유전자의 발현이 억 제됨을 보였다.

본 실험은 keratinocyte가 $\mathrm{NO}$ 에 의해 apoptosis가 일어나며 caspase 3의 활성과 PARP의 절단이 관여하며 ER stress와 연관성 은 약한 듯 하고 $\operatorname{sirt1}$ 의 발현이 억제됨을 보여준다. 하지만 NO에 의한 $\operatorname{sirt1}$ 의 발현 억제와 apoptosis가 직접 관련 있음을 보이는 증 거는 아니다. 따라서 $\operatorname{sirt1}$ 억제 혹은 과발현 실험을 통해 $\mathrm{NO}$ 에 의 한 sirt1 발현 조절이 apoptosis와 직접 관련 있음을 밝혀야 하며 이 런 기전과 피부 생리학 및 병리학적 의미와 연결 지을 수 있어야한 다고 생각한다.

\section{요 약}

산화질소(Nitric Oxide, $\mathrm{NO}$ )는 생리학적, 병리학적으로 주요한 역할을 하고 있는 것으로 알려져 있다. 본 실험에서는 NO donor인 sodium nitroprusside (SNP)가 HaCaT 세포에서 apoptosis를 유 도한다는 것을 DAPI염색과 PARP, caspase-3 단백질 절단을 western blot으로 확인하였다. SNP는 ER stress와 관련 있는 Bip, $C H O P$ 유전자 발현에는 영향이 없었다. 최근 $\mathrm{NAD}+$ 의존 deacetylase 인 sirt1이 세포의 생존 및 사멸에 매우 중요한 단백질이라는 보고 가 있다. 본 실험에서 $\mathrm{SNP}$ 는 $\mathrm{HaCaT}$ 세포의 $\operatorname{sirt1}$ 유전자 발현을 감 소시켰으며 이는 apoptosis와 관련이 있을 수 있다.

Acknowledgment: 이 논문은 2014학년도 세명대학교 교내학 술연구비 지원에 의해 수행된 연구임. 
Funding: 2014학년도 세명대학교 교내학술연구비

Conflict of interest: None

\section{References}

1. Bastianetto S, Dumont Y, Duranton A, Vercauteren F, Breton L, Quirion R. Protective Action of Resveratrol in Human Skin: Possible Involvement of Specific Receptor Binding Sites. PLOS ONE. 2010, 5(9):e12935.

2. Cao C, Lu S, Kivlin R, Wallin B, Card E, Bagdasarian A, Tamakloe T, Wang WJ, Song X, Chu WM, Kouttab N, Xu A, Wan Y. SIRT1 confers protection against UVB- and $\mathrm{H} 2 \mathrm{O} 2$-induced cell death via modulation of $\mathrm{p} 53$ and JNK in cultured skin keratinocytes. J. Cell. Mol. Med. 2009, 13(9B):3632-43.

3. Chae HJ, So HS, Chae SW, Park JS, Kim MS, Oh JM, Chung YT, Yang SH, Jeong ET, Kim HM, Park RK, Kim HR. Sodium nitroprusside induces apoptosis of $\mathrm{H} 9 \mathrm{C} 2$ cardiac muscle cells in a c-Jun N-terminal kinase-dependent manner. Int. Immunopharmacol. 2001, 1(5):967-978.

4. Chen RM, Liu HC, Lin YL, Jean WC, Chen JS, Wang JH. Nitric oxide induces osteoblast apoptosis through the de novo synthesis of Bax protein. J Orthop Res. 2002, 20(2):295-302.

5. Deliconstantinos G, Villiotou V, Stravrides JC Release by ultraviolet $B$ (u.v.B) radiation of nitric oxide (NO) from human keratinocytes: a potential role for nitric oxide in erythema production. Br.J. Pharmacol. 1995, 114(6), 1257-1265.

6. Kawahara K, Oyadomari S, Gotoh T, Kohsaka S, Nakayama H, Mori M. Induction of $\mathrm{CHOP}$ and apoptosis by nitric oxide in p53-deficient microglial cells. FEBS Lett. 2001, 506(2), 135-139.

7. Herbert KJ, Cook AL, Snow ET. SIRT1 inhibition restores apoptotic sensitivity in p-53 mutated human keratinocytes. Toxicol. Appl. Pharmacol. 2014, 277,288-297.

8. Hughes KJ, Meares GP, Hansen PA, Corbett JA. FoxO1 and SIRT1
Regulate $\beta$-Cell Responses to Nitric Oxide. J. Biol. Chem. 2011, 286, 8338-8348.

9. Luo J, Nikolaev AY, Imai S, Chen D, Su F, Shiloh A, Guarente L, $\mathrm{Gu}$ W. Negative control of p53 by Sir2 $\alpha$ promotes cell survival under stress. Cell. 2001, 107:137-148.

10. Messmer UK, Brune B, Nitric oxide-induced apoptosis: p53dependent and p53-independent signalling pathways. Biochem. J. 1995, 319, 299-305.

11. Oyadomari S, Takeda K, Takiguchi M, Gotoh T, Matsumoto M, Wada I, Akira S, Araki E, Mori M. Nitric oxide-induced apoptosis in pancreatic $\beta$ cells is mediated by the endoplasmic reticulum stress pathway. Proc Natl Acad SCi USA. 2001, 98(19), 10845-10850.

12. Romero-Graillet C, Aberdam E, Clement M, Ortonne JP, Ballotti R Nitric Oxide Produced by Ultraviolet-irradiated Keratinocytes Stimulates Melanogenesis. J, Clin. Invest. 1997, 99(4), 635-642.

13. Spitler R, Schwappacher R, Wu T, Kong X, Yokomori K, Pilz RB, Nitrosyl-cobinamide (NO-Cbi), a new nitric oxide donor, improves wound healing through cGMP/cGMP-dependent protein kinase. Cell Signal. 2013, 25: 2374-2382.

14. Takada K, Hirose J, Yamabe S, Uehara Y, Mizuta H. Endoplasmic reticulum stress mediates nitric oxide-induced chondrocyte apoptosis. Biomed Rep. 2013, 1(2), 315-319.

15. Weller R, Schwentker A, Billiar TR, Vodovotz Y. Autologous nitric oxide protects mouse and human keratinocytes form ultraviolet B radiation-induced apoptosis. Am J Physiol Cell Physiol. 2003, 284, 1140-1148.

16. Yeung F, Hoberg JE, Ramsey CS, Keller MD, Jones DR, Frye RA, Mayo MW. Modulation of NF- $\kappa \mathrm{B}$-dependent transcription and cell survival by the SIRT1 deacetylase. EMBOJ. 2004, 23, 23692380 .

17. Zhan R, Yang S, He W, Wang F, Tan J, Zhou J, Yang S, Yao Z, Wu J, Luo G. Nitric oxide enhances keratinocyte cell migration by regulating Rho GTPase via cGMP-PKG signalling. PLoS One. 2015, 10(3):e0121551. 